\author{
JURNAL LAMPUHYANG \\ LEMBAGA PENJAMINAN MUTU \\ STKIP AGAMA HINDU AMLAPURA
}

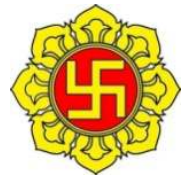

Volume 13 Nomor 1 Januari 2022

p-ISSN: 2087-0760; e-ISSN: 2745-5661

https://e-journal.stkip-amlapura.ac.id

\title{
Penerapan Pendekatan Saintifik untuk Meningkatkan Hasil Belajar IPA Siswa Kelas IV Semester I SD Negeri 2 Subagan
}

\author{
Ni Ketut Putri \\ SD Negeri 2 Subagan \\ iketutputri@yahoo.co.id
}

Direvisi: 20 November 2021

Diterima: 24 Desember 2021

Diterbitkan: 1 Januari 2022

\begin{abstract}
Abstrak: Penelitian Tindakan Kelas (PTK) yang dilaksanakan di kelas IV SD Negeri 2 Subagan bertujuan untuk mengetahui apakah penerapan pendekatan Saintifik dapat meningkatkan hasil belajar siswa bagi siswa kelas IV pada SD Negeri 2 Subagan Tahun Pelajaran 2019/2020. Data terkait hasil belajar dikumpulkan dengan menggunakan tes. Hasil penelitian pada data kognitif pada siklus I menunjukkan bahwa dari 17 siswa ada 2 siswa yang belum tuntas dalam pembelajaran presentase anak yang tidak tuntas adalah $11,76 \%$, sedangkan siswa yang tuntas berjumlah 15 orang dengan presentase $88,24 \%$ nilai modus pada siklus I adalah 60. Pada siklus II tidak ada siswa yang tidak tuntas dan siswa yang tuntas dalam pembelajaran berjumlah 17 orang sehingga yang tuntas $100 \%$ dengan nilai modus siklus II adalah 70 .

Kata Kunci: Pendekatan Saintifik, hasil belajar

Abstract: Classroom Action Research which was conducted in grade IV of SD Negeri 2 Subagan aims to determine whether the application of the Scientific approach can improve student learning outcomes for grade IV students at SD Negeri 2 Subagan for the 2019/2020 academic year. Data related to learning outcomes were collected using tests. The results of the research on cognitive data in the first cycle showed that from 17 students there were 2 students who had not completed learning the percentage of children who did not complete was $11.76 \%$, while the students who completed were 15 people with a percentage of $88.24 \%$ of the mode scores in the first cycle. is 60 . In the second cycle there are no students who are incomplete and the students who complete the learning are 17 people so that those who complete $100 \%$ with the value of the second cycle mode are 70 .
\end{abstract}

Keywords: Scientific Approach, learning outcomes 


\section{PENDAHULUAN}

\subsection{Latar Belakang}

Dalam proses pembangunan Nasional Pendidikan merupakan bagian yang sangat penting dan tidak dapat dipisahkan, oleh karena itu pembangunan di bidang pendidikan merupakan salah satu upaya meningkatkan sumber daya manusia agar mampu bersaing dalam menghadapi perkembangan zaman. Sesuai dengan pendapat yang diuraikan Ihsan (2008:1) bahwa: "Pendidikan adalah sebagai usaha manusia untuk menumbuhkan dan mengembangkan potensi-potensi pembawaan baik jasmani maupun rohani sesuai dengan nilai-nilai yang ada di dalam masyarakat dan kebudayaan". Karena begitu pentingnya bidang pendidikan maka komponen yang terkait dalam dunia pendidikan baik keluarga, masyarakat dan juga pemerintah terus melakukan berbagai upaya untuk meningkatkan kualitas pendidikan.

Terdapat empat strategi dalam pendidikan yang direkomendasikan oleh Komisi Pendidikan Abad ke-21 (Commission on Education for the "21", Century) antara lain, (1) learning to learn, yaitu membuat pelajar mampu menggali informasi yang ada di sekitarnya dari ledakan informasi itu sendiri. (2) Learning to be, yaitu pelajar diharapkan mampu mengenal dirinya sendiri serta beradaptasi dengan lingkungannya. (3) Learning to do, yaitu berupa tindakan atau aksi. (4) Learning to be together, yaitu membuat kita hidup dalam masyarakat yang saling bergantung antara yang satu dan yang lain, sehingga mampu bersaing secara sehat dan bekerja sama serta mampu untuk menghargai orang lain (Trianto, 2009). Untuk mewujudkan hal tersebut, salah satu cara yang dapat ditempuh adalah menerapkan pembelajaran yang melibatkan peserta didik secara aktif. Guru dalam proses pembelajaran di kelas mampu menciptakan pembelajaran yang membuat peserta didik menjadi aktif dan terjalin interaksi yang baik.

Pembelajaran adalah suatu proses interaksi peserta didik dengan peserta didik lainnya, peserta didik dengan sumber belajar, dan peserta didik dengan pembelajaran (Yamin, 2011). Interaksi dalam pembelajaran akan terjadi secara menarik jika pembelajaran bermakna bagi peserta didik, dalam artian yang dipelajari 182 
di sekolah tidak hanya berupa hafalan teori tetapi juga bisa bermanfaat dan bisa diterapkan dalam kehidupannya. Pembelajaran bermakna akan terjadi apabila proses pembelajaran dilaksanakan secara menyenangkan. Pembelajaran yang menyenangkan akan tercipta jika melibatkan peserta didik secara aktif dalam pembelajaran. Permediknas No. 41 tentang Standar Proses menuntut proses pembelajaran hendaknya berpusat pada peserta didik. Peserta didik ikut aktif dalam pembelajaran sehinga peserta didik menjadi termotivasi dalam pembelajaran. Pemerintah telah berusaha untuk memperbaiki proses pembelajaran yang terjadi di dalam kelas.

Paragdima lama memandang bahwa guru merupakan sosok yang tahu segalanya di kelas. Namun, dewasa ini paragdima ini diharapkan diganti guru bukan sumber utama, tetapi teman belajar bagi peserta didik. Dahulu kegiatan pembelajaran disebut "proses belajar mengajar", tetapi sekarang digeser menjadi proses pembelajaran. Dari pergeseran ini diketahui bahwa "pembelajaran" bermakna peserta didik dan guru sama-sama belajar. Peserta didik aktif menggali pembelajaran begitu juga guru berusaha untuk belajar hal-hal yang baru, serta keilmuan yang ada, termasuk mengemas proses pembelajaran dari yang semula berpusat pada guru supaya menjadi berpusat pada peserta didik. Namun dalam kenyataannya, guru masih saja memposisikan diri sebagai sumber belajar, tidak memberikan akun bagi anak didik untuk berkembang secara mandiri melalui penemuan proses berpikirnya. Keadaan ini perlu diubah dengan menerapkan model-model pembelajaran yang berpusat pada peserta didik.

Meningkatkan kualitas pembelajaran merupakan salah satu hal yang penting yang harus diperhatikan dalam suatu proses belajar mengajar untuk meningkatkan mutu pendidikan. Hal ini merupakan tugas masing-masing sekolah dan yang paling utama adalah guru sebagai tenaga pengajar. Di sinilah dituntut kemampuan guru untuk berpikir kreatif dalam melakukan pembelajaran agar siswa lebih mudah memahami materi yang disampaikan dan siswa menjadi antusias dalam mengikuti proses belajarmengajar sehingga pembelajaran yang dilaksanakan berkualitas dan hasil belajar yang dicapai siswa memuaskan. "Berpikir kreatif berarti menemukan cara-cara baru 
untuk mengerjakan apa saja" (Schwart dalam Ihsan, 2008). Bagi seorang guru, menggunakan strategi pembelajaran tertentu yang relevan yang dapat menciptakan iklim belajar yang kondusif dan mampu meningkatkan hasil belajar siswa yang disesuaikan dengan kondisi siswa, lingkungan kelas, lingkungan sekolah dan budaya dimana sekolah tersebut berada merupakan cara berpikir kreatif. Strategi dalam kaitannya dengan pembelajaran IPA yang dimaksud adalah siasat atau cara yang sengaja direncanakan oleh guru berkenaan dengan segala persiapan pembelajaran IPA di kelas.

Berdasarkan hasil Pra Siklus siswa (sumber: daftar Nilai PraSiklus kelas IV SD Negeri 2 Subagan) ternyata masih banyak siswa yang memiliki nilai rendah, belum mencapai KKM, baru $76,47 \%$ di atas KKM. Kriteria Ketuntasan Minimal (KKM) mata pelajaran IPA yang ditetapkan oleh sekolah (SD Negeri 2 Subagan) adalah 60. Hal ini bisa disebabkan karena proses pembelajaran IPA yang dilakukan selama ini belum mencerminkan adanya pembelajaran IPA yang membuat siswa merasa senang dan tertarik dalam proses pembelajaran.
Pembelajaran dengan pendekatan saintifik adalah proses pembelajaran yang dirancang sedemikian rupa agar peserta didik secara aktif mengonstruk konsep, hukum atau prinsip melalui tahapantahapan mengamati (untuk mengidentifikasi atau menemukan masalah), merumuskan masalah, mengajukan atau merumuskan hipotesis, mengumpulkan data dengan berbagai teknik, menganalisis data, menarik kesimpulan dan mengomunikasikan konsep, hukum, atau prinsip yang ditemukan. Proses pembelajaran dengan berbasis pendekatan ilmiah harus dipandu dengan kaidah-kaidah pendekatan ilmiah. Langkah-langkah pada pendekatan saintifik merupakan bentuk adaptasi dari langkah-langkah ilmiah pada sains. Proses pembelajaran dapat dipadankan dengan suatu proses ilmiah. Oleh karena itu, Kurikulum 2013 mengamanatkan esensi pendekatan saintifik dalam pembelajaran. Pendekatan Saintifik diyakini sebagai titian emas perkembangan dan pengembangan sikap, keterampilan, dan pengetahuan peserta didik. pembelajaran dengan pendekatan Saintifik sudah mesti dilakukan oleh 
sekolah dan dilaksanakan oleh guru yang telah menerapkan kurikulum 2013.

Pendekatan saintifik memiliki beberapa karakteristik sebagai berikut: 1 . berpusat pada siswa; 2. melibatkan keterampilan proses sains dalam mengonstruksi konsep, hukum atau prinsip; 3. melibatkan proses-proses kognitif yang potensial dalam merangsang perkembangan intelek, khususnya keterampilan berpikir tingkat tinggi siswa; 4. dapat mengembangkan karakter siswa; Beberapa tujuan pembelajaran dengan pendekatan saintifik adalah: 1) untuk meningkatkan kemampuan intelek, khususnya kemampuan berpikir tingkat tinggi siswa; 2) untuk membentuk kemampuan siswa dalam menyelesaikan suatu masalah secara sistematik; 3) terciptanya kondisi pembelajaran dimana siswa merasa bahwa belajar itu merupakan suatu kebutuhan; 4) di perolehnya hasil belajar yang tinggi (Asrining Surasmi,Wuwuh.2019).

Berdasarkan latar belakang di atas maka perlu diadakan penelitian dengan menerapkan pendekatan saintifik. Pendekatan Saintifik ini dapat mendukung tercapainya tujuan pembelajaran IPA serta menimbulkan motivasi belajar siswa sehingga mampu meningkatkan hasil belajar siswa. Penelitian yang akan dilakukan berjudul "Penerapan Pendekatan Saintifik untuk meningkatkan hasil belajar IPA siswa kelas IV SD Negeri 2 Subagan Semester 1 Tahun Pelajaran 2019/2020". Harapan dalam penelitian ini adalah penerapan pendekatan saintifik dapat mendukung pembelajaran IPA serta siswa lebih aktif dalam pembelajaran dan hasil belajar siswa bisa lebih baik

\subsection{Rumusan Masalah}

Adapun rumusan masalah yang dapat dibuat adalah: Apakah penerapan pendekatan saintifik dapat meningkatkan hasil belajar IPA siswa kelas IV SD Negeri 2 Subagan Semester 1 Tahun Pelajaran 2019/2020?

\subsection{Tujuan Penulisan}

Tujuan dari penulisan ini adalah untuk mengetahui apakah penerapan pendekatan saintifik dapat meningkatkan hasil belajar siswa IPA kelas IV SD Negeri 2 Subagan Semester 1 Tahun Pelajaran 2019/2020? 


\subsection{Manfaat Penelitian}

Manfaat penelitian ini secara praktis dirasakan oleh siswa dalam rangka meningkatkan hasil belajar siswa dan membantu siswa dalam meningkatkan minat dan fokus dalam proses pembelajaran, khususnya materi IPA. Bagi guru, hasil penelitian ini sebagai alternatif proses pembelajaran IPA di sekolah. Bagi lembaga pendidikan, dapat dijadikan bahan masukan dalam upaya meningkatkan kualitas dan mutu pendidikan di sekolah.

\section{TINJAUAN PUSTAKA}

\subsection{Pendekatan Saintifik}

Pengertian Pendekatan Saintifik merujuk pada teknik-teknik investigasi atas fenomena atau gejala, memperoleh pengetahuan baru, atau mengoreksi dan memadukan pengetahuan sebelumnya. Sedangkan menurut Lazim (2013), Pendekatan saintifik didefinisikan sebagai berikut, Pendekatan saintifik adalah proses pembelajaran yang dirancang sedemikian rupa agar peserta didik secara aktif mengonstruk konsep, hukum atau prinsip melalui tahapan-tahapan mengamati (untuk mengidentifikasi atau menemukan masalah), merumuskan masalah, mengajukan atau merumuskan hipotesis, mengumpulkan data dengan berbagai teknik, menganalisis data, menarik kesimpulan dan mengomunikasikan konsep, hukum atau prinsip yang ditemukan. Dari pengertian di atas dapat disimpulkan bahwa pendekatan saintifik adalah suatu teknik pembelajaran yang menempatkan siswa menjadi subjek aktif melalui tahapantahapan ilmiah sehingga mampu mengkonstruksi pengetahuan baru atau memadukan dengan pengetahuan sebelumnya.

\subsection{Hasil Belajar}

Belajar merupakan proses psikologis yaitu perubahan perilaku peserta didik, baik berupa pengetahuan, sikap, ataupun ketrampilan. Proses belajar yang terjadi pada diri peserta didik selain dipengaruhi oleh faktor internal yang bersangkutan, juga dapat dipengaruhi oleh faktor lingkungan atau faktor eksternal lainnya. Skiner (Budiningsih, 2006:15) berpendapat bahwa belajar adalah suatu perubahan perilaku. Pada saat orang belajar maka responnya menjadi lebih baik sebaliknya apabila 186 
seseorang tidak belajar, maka responnya cenderung menurun.

Arikunto (2007:133) mengatakan bahwa hasil belajar adalah hasil akhir setelah mengalami proses belajar, perubahan itu tampak dalam perbuatan yang dapat diaamati,dan dapat diukur". Hasil belajar adalah kemampuankemampuan yang dimiliki siswa setelah ia menerima pengalaman belajarnya. Individu yang belajar akan memperoleh hasil dari apa yang telah dipelajari selama proses belajar itu. "Hasil belajar yaitu suatu perubahan yang terjadi pada individu yang belajar, bukan hanya perubahan mengenai pengetahuan, tetapi juga untuk membentuk kecakapan, kebiasaan, pengertian, penguasaan, dan penghargaan dalam diri seseorang yang belajar"

Pada umumnya hasil belajar dapat dikelompokkan menjadi tiga ranah, yaitu ranah kognitif, afektif, dan psikomotor. Secara eksplisit, ketiga ranah ini tidak dapat dipisahkan satu sama lain. Setiap mata ajar selalu mengandung ketiga ranah tersebut, tetapi penekanannya selalu berbeda. Mata ajar praktik lebih menekankan pada ranah psikomotor, sedangkan mata ajar pemahaman konsep lebih menekankan pada ranah kognitif dan kedua ranah tersebut mengandung ranah afektif.

\section{METODE PENELITIAN}

Penelitian ini tergolong penelitian tindakan kelas (classroom action research) yang secara umum bertujuan untuk meningkatkan dan memperbaiki kegiatan pembelajaran di sekolah pada umumnya dan dalam kelas pada khususnya (Arikunto, 2010:3). Subyek yang dipilih dalam penelitian ini adalah siswa-siswa kelas IV SD Negeri 2 Subagan Semester 1 Tahun Pelajaran 2019/2020 dengan jumlah 17 siswa. Siswa perempuan berjumlah 8 orang dan siswa laki-laki berjumlah 9 orang. Adapun objek dalam penelitian ini adalah: hasil belajar siswa (aspek kognitif).

Teknik pengumpulan data serta instrumen penelitian untuk masingmasing jenis data dalam penelitian ini dapat dilihat pada Tabel 1 berikut. 
Tabel 1 Jenis Data, Teknik Pengumpulan Data dan Instrumen Penelitian

\begin{tabular}{|c|c|l|l|l|}
\hline No & \multicolumn{1}{|c|}{ Jenis Data } & \multicolumn{1}{c|}{$\begin{array}{c}\text { Metode } \\
\text { Pengumpulan } \\
\text { Data }\end{array}$} & $\begin{array}{c}\text { Instrumen } \\
\text { Penelitian }\end{array}$ & \multicolumn{1}{|c|}{ Waktu } \\
\hline 1. & Aspek Kognitif & $\begin{array}{l}\text { Hasil Diskusi, dan } \\
\text { tes }\end{array}$ & $\begin{array}{l}\text { Tugas diskusi dan } \\
\text { tes }\end{array}$ & $\begin{array}{l}\text { Setiap } \\
\text { pertemuan, } \\
\text { tetapi tes } \\
\text { setiap akhir } \\
\text { siklus }\end{array}$ \\
\hline
\end{tabular}

Hasil belajar siswa yang dinilai yaitu, simpangan baku, dan presentase. data aspek kognitif (pengetahuan), terhadap kognitif menggunakan pedoman KKM Penerapan pendekatan saintifik. Analisis kelas IV SD Negeri 2 Subagan tahun deskriptif digunakan untuk pelajaran 2019/2020 yang disesuaikan mendeskripsikan skor rata-rata, dengan kurikulum 2013.

Nilai rerata dicari dengan rumus : $\bar{x}=\frac{\sum x}{n}$

Keterangan :

$\bar{x} \quad=$ Nilai rata-rata siswa

$\sum x=$ Jumlah seluruh nilai yang diperoleh siswa

$\mathrm{n}=$ Jumlah aspek yang diukur pada tiap siswa

Kategori nilai siswa berdasarkan KKM dengan kurikulum 2013 adalah seperti kelas IV SD Negeri 2 Subagan tahun Tabel 02.

pelajaran 2019/2020 yang disesuaikan 
Tabel 2 Pedoman Konversi Kognitif Siswa

\begin{tabular}{|c|c|c|}
\hline No & Rentang Nilai & Kategori \\
\hline 1 & $\geq 60$ & Tuntas \\
\hline 2 & $<60$ & tidak tuntas \\
\hline
\end{tabular}

Sumber : KKM kelas IV SD Negeri 2 Subagan tahun pelajaran 2019/2020

Penelitian Penerapan pendekatan saintifik uintuk meningkatkan hasil belajar siswa kelas IV SD Negeri 2 Subagan Semester 1 Tahun Pelajaran 2019/2020 dikatakan berhasil, jika hasil belajar siswa mencapai rata-rata 60 dari ketuntasan klasikal siswa adalah 95\%.

\section{HASIL DAN PEMBAHASAN}

Hasil penelitian pada siklus I dan siklus II ini dapat dilihat pada Tabel 3 berikut.

Tabel 3 Hasil Belajar Siklus I dan Siklus II

\begin{tabular}{|c|l|l|l|l|}
\hline $\begin{array}{l}\text { Nilai Hasil } \\
\text { Belajar }\end{array}$ & \multicolumn{1}{|c|}{$\begin{array}{c}\text { Penerapan } \\
\text { Pendekatan } \\
\text { Saintifik }\end{array}$} & Rata-rata & Ketuntasan & Modus \\
\hline \multirow{2}{*}{ Kognitif } & Siklus I & 65.59 & 88.24 & 60 \\
\cline { 2 - 6 } & Siklus II & 76.76 & 100 & 70 \\
\hline
\end{tabular}

Grafik dari nilai rata-rata hasil

Subagan Tahun Pelajaran 2019/2020 belajar kognitif IPA siswa pada siklus I dapat dilihat pada gambar grafik di bawah dan siklus II di kelas IV SD Negeri 2 ini. 


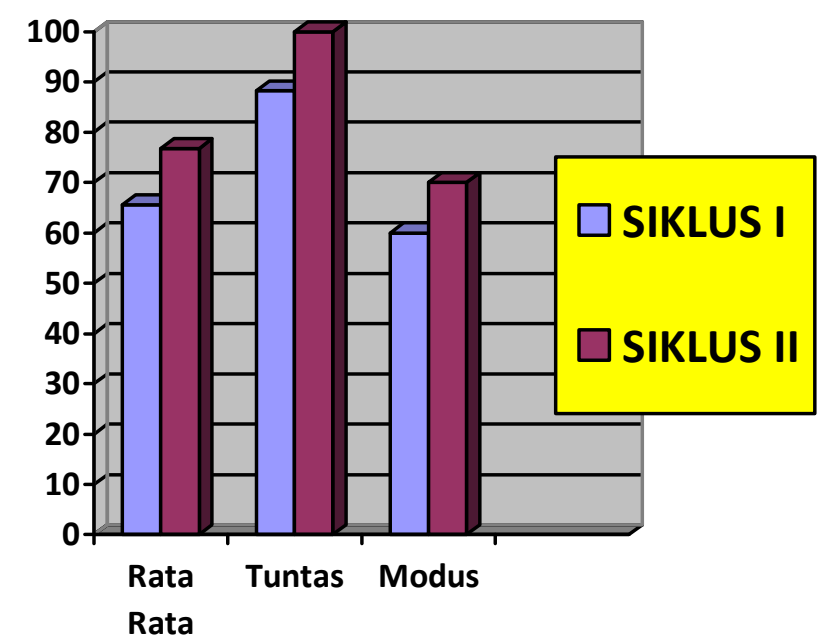

\section{Gambar 01 : Grafik Nilai Rata-rata Hasil Ketuntasan dan Modus Hasil Belajar Kognitif Siklus I dan Siklus II Terhadap Penerapan Pendekatan Saintifik}

\subsection{Pembahasan}

Hasil penelitian pada data kognitif pada Pra siklus menunjukkan bahwa ada 4 anak dari 17 siswa yang tidak tuntas dalam pembelajaran karena nilainya berada dibawah KKM $(<60)$ presentase anak yang tidak tuntas adalah 23,53\% sedangkan yang tuntas adalah 76,47\% nilai modusnya adalah 60 , sedangkan data kognitif pada siklus I menunjukkan bahwa dari 17 siswa ada 2 siswa yang belum tuntas dalam pembelajaran presentase anak yang tidak tuntas adalah $11,76 \%$, sedangkan siswa yang tuntas berjumlah 15 orang dengan presentase $88,24 \%$ nilai modus pada siklus I adalah
60. Pada siklus II tidak ada siswa yang tidak tuntas dan siswa yang tuntas dalam pembelajaran berjumlah 17 orang sehingga yang tuntas $100 \%$ dengan nilai modus siklus II nya adalah 70. Maka dari data tersebut, tidak perlu dilanjutkan ke siklus berikutnya karena sudah memenuhi kriteria keberhasilan yaitu diatas 95\% .

Hasil observasi pada siklus I menunjukkan bahwa hasil kognitif masih ada 2 siswa yang nilainya masih ada di bawah standar kelulusan. Siswa masih ragu dalam dalam mengerjakan LKS. Masih ada perbaikan perbaikan yang penulis lakukan di LKS selanjutnya. Dari analisis hasil pada siklus I dijadikan 190 
acuan pada perbaikan proses belajar di siklus II. Pada siklus II terjadi peningkatan dari rata rata 76,47 menjadi 88,24 Hal ini diakibatkan siswa sangat antusias mengerjakan LKS dan berdiskusi dalam kelompok sehingga gairah belajarnya meningkat dan hal ini akan berkolerasi positif terhadap hasil belajar kognitif siswa.

Hasil tanggapan siswa mengenai penerapan pendekatan saintifik menunjukkan bahwa siswa di SD Negeri 2 Subagan merasa senang dengan proses pembelajaran tersebut karena dengan Pendektan saintifik siswa diberikan keleluasaan untuk mencari literature pendukung sebanyak banyaknya, diberikan kesempatan menanyakan hal hal yang kurang jelas baik sebelum dan setelah pembelajaran, siswa dapat bekerja sama dalam kelompoknya ketika mengerjakan LKS yang diberikan oleh guru, selain itu siswa juga diberikan kesempatan untuk mempresentasikan hasil kerjanya dalam kelompok serta mengemukakan kesimpulan yang sudah mereka rangkum dari kegiatan pembelajaran yang telah berlangsung. Ketertarikan dan tanggapan positif yang ditunjukkan siswa ini dipengaruhi adanya komunikasi baik diantara teman teman di kelompok diskusinya juga terhadap gurunya sebagai pembimbing di kelas tersebut. Menurut tanggapan siswa, penerapan pendekatan Saintifik merupakan hal yang baru, karena bentuk cara belajar sangat menarik. Selain itu kegiatan presentasi juga memberi rasa percaya diri kepada siswa untuk menyampaikan hasil diskusi atau untuk mengutarakan isi pikirannya. Penerapan pendekatan saintifik berbantuan juga bersifat menumbuhkan interaksi antar siswa dengan adanya diskusi, sehingga dalam menyelesaikan soal-soal menumbuhkan rasa kerjasama dalam satu kelompok. Penerapan pendekatan saintifik berbantuan juga mempunyai informasi tambahan seperti info materi yang sudah dipelajari siswa sehingga siswa dapat mengingat kembali materi tersebut. Menurut siswa Penerapan pendekatan saintifik sebaiknya tidak hanya diberikan pada materi IPA kelas IV semester 1 saja, akan tetapi pada materi IPA yang lain. Hal ini dimaksudkan agar siswa lebih memahami tentang materi IPA dan menumbuhkan keaktifan siswa dalam pembelajaran dengan adanya 
kegiatan diskusi maupun kegiatan yang lain.

Hasil penelitian ini menunjukkan bahwa penerapan pendekatan saintifik efektif digunakan dalam pembelajaran. Pendekatan Saintifik memberikan efek yang positif pada aktivitas dan hasil belajar siswa. Penelitian ini sesuai dengan hasil penelitian yang dilakukan oleh Sukmaningtyas (2011), bahwa penerapan pendekatan Saintifik dapat meningkatkan hasil belajar siswa sebesar $80,09 \%$ secara klasikal.

Berdasarkan Indikator keberhasilan maka penelitian ini dapat dikatakan berhasil. Hasil belajar siswa telah mencapai diatas rata rata 60 yaitu 88,24 dan ketuntasan klasikal sudah diatas $95 \%$ yaitu $100 \%$ tuntas.

\section{PENUTUP}

Berdasarkan hasil penelitian dan pembahasan yang telah dikemukakan, dapat diambil simpulan sebagai berikut. Penerapan pendekatan saintifik meningkatkan hasil belajar siswa kelas IV SD Negeri 2 Subagan Tahun Pelajaran 2019/2020. Dari Hasil penelitian pada data kognitif pada siklus I menunjukkan bahwa dari 17 siswa ada 2 siswa yang belum tuntas dalam pembelajaran presentase anak yang tidak tuntas adalah $11,76 \%$, sedangkan siswa yang tuntas berjumlah 15 orang dengan presentase $88,24 \%$ nilai modus pada siklus I adalah 60. Pada siklus II tidak ada siswa yang tidak tuntas dan siswa yang tuntas dalam pembelajaran berjumlah 17 orang sehingga yang tuntas $100 \%$ dengan nilai modus siklus II nya adalah 70 .

Saran yang dapat direkomendasikan dari hasil penelitian ini, yaitu: penerapan pendekatan saintifik ini dapat diterapkan pada siswa dengan jenjang yang berbeda. Penelitian ini dapat dilanjutkan pada materi IPA di kelas V ataupun di kelas lainnya. Sekolah dapat membantu guru di dalam menyediakan sarana prasarana lebih baik demi menunjang kualitas pendidikan yang lebih baik.

\section{DAFTAR PUSTAKA}

Abu Ahmadi. 2009. Psikologi Umum. Jakarta : Rineka Cipta

Andang Ismail. 2006. Education Games. Yogyakarta: Pilar Media.

Arikunto, S. 2007. Dasar-Dasar Evaluasi Pendidikan. Jakarta: Bumi Aksara.

Arikunto, S. 2010. Prosedur Penelitian Suatu Pendekatan Praktik. Jakarta: RinekaCipta. 
Arsyad, A. 2004. Media Pembelajaran. Jakarta: PT Raja Grafindo Persada.

Asrining Surasmi,Wuwuh.2019. Penerapan Pendekatan Saintifik Dalam Proses Pembelajaran Kurikulum 2013. Artikel : Universitas Terbuka UPBJJ Surabaya

Budiningsih, A. 2006. Belajar dan pembelajaran. Jakarta: Rineka Cipta.

Devi, P. P., R. Sofiraeni, \& Khairuddin. 2009. Pengembangan Perangkat Pembelajaran untuk Guru SMP. Bandung: PPPPTK IPA.

Dimyati dan Mudjiono.2006. Belajar dan Hasil Belajar.Jakarta: Rineka Cipta

Ihsan, Fuad.2008. Dasar-dasar Kependidikan. Jakarta: Rineka Cipta

John M Echols dan Hasan Shadily. 2000 Kamus Inggris Indonesia An English-Indonesia Dic tionary. Jakarta :PT Gramedia

Kaymacki, S. 2012. A Review of Studies on Worksheets in Turkey. Jurnal of US-China Education. Hal 57-64.

Lazim 2013. Pendekatan Sientifik Learning. Jakarta : PT Raja Grafindo Persada

Mulyono, P. 2007. Kegiatan Penilaian Buku Teks Pelajaran Pendidikan Dasar dan Menengah. Buletin BSNP. Hlm. 14-23.

National Council of Educational Research and Training. 2006. National Focus
Group on Teaching Science. Newdelhi P. Rajakumar.

Nurkancana dann Sunartana. 1992. Evaluasi Pendidikan. Surabaya: Usaha Nasional

Peraturan Menteri Pendidikan Nasional Republik Indonesia. 2006. Peraturan Menteri Pendidikan Nasional Republik Indonesia Nomor 22 Tahun 2006 Tentang Standar Isi untuk Satuan Pendidikan Dasar dan Menengah.

Sukmaningtyas. 2011. Penerapan Pendekataqn Saintifik pada Pembelajaran IPA TERPADU Di SMP Negeri 2 Pangkah Kabupaten Tegal. Skripsi.Semarang: FMIPA Universitas Negeri Semarang.

Trianto, 2012. Model Pembelajaran Terpadu Konsep, Srategi, dan Implementasinya dalam KTSP. Jakarta :Bumi Aksara.

Trianto. 2009. Model Mendesain Pembelajaran Inovatif- progresif. Kencana:Jakarta.

Wiyanto. 2015. Menyiapkan Guru Sains Mengembangkan Kompetensi Laboratorium. Semarang: UNNES Press.

Yamin, Martinis. 2011. Pragdima Baru Pembelajaran.GP press: Jakarta.

Yildrim, N., S. Kurt, \& A. Ayas. 2011. The Effect Of The Worksheets On Students Achievement In Chemical Equilibrium. Journal Of Turkish Science Education Vol. 8. Hlm 4558. 